\title{
Helicobacter pylori: a beneficial gastric pathogen?
}

\author{
Amin Talebi Bezmin Abadi ${ }^{1,2}$ * \\ ${ }^{1}$ Department of Medical Microbiology, University Medical Center Utrecht, Utrecht, Netherlands \\ ${ }^{2}$ Department of Bacteriology, Faculty of Medical Sciences, Tarbiat Modares University, Tehran, Iran \\ ${ }^{*}$ Correspondence: amin.talebi@gmail.com \\ Edited by: \\ Yeong Yeh Lee, Universiti Sains Malaysia, Malaysia \\ Reviewed by: \\ Yeong Yeh Lee, Universiti Sains Malaysia, Malaysia \\ Alejandro Piscoya, Universidad Peruana de Ciencias Aplicadas, Peru
}

Keywords: Helicobacter pylori, pathogen, digestive diseases, human gastric mucosa, colonization, GERD

\section{INTRODUCTION}

Since Helicobacter pylori ( $H$. pylori) is the first successful culture three decades ago, ongoing perspectives regarding the relationship between the bacterium and human health have changed radically $(1,2)$. Apart from tremendous studies performed during the last years, there are still many debates regarding the unclear rationale for existence of such bacteria in human stomach $(3,4)$. Basically, due to the beneficiary effects of $H$. pylori colonization (regression in child asthma and other allergic disorders), it has been concluded that $H$. pylori is a common flora or at least harmless bacterium (5-10), Conversely, because of the causative role of $H$. pylori in certain digestive diseases such as duodenal ulcer and gastric cancer, other reports are quite contradictory (11-13). A large number of discussions led to a consensus regarding presence of $H$. pylori in the human stomach $(5,11,14,15)$. Our knowledge about biology of $H$. pylori suggests that the bacterium is highly adapted to stay in gastric mucosa for long time $(1,16)$. Indeed, living in lower surface of gastric mucosa, with no bacterial competition, provided a novel place to survive. Moreover, H. pylori is able to multiply freely due to the protective effects by mucosal layer. Thus, $H$. pylori had an opportunity to thrive in stomach over the course of tens of thousands of years of co-evolution with humans (17). Additionally, the high frequency of mutation in the genome also led to higher chances of survival, and natural selection helped them to remain and cause chronic infection (18). Determining whether $H$. pylori is beneficial or detrimental in human stomach has been a challenging area of research in gastroenterology $(5,11,19,20)$. In this article, we aim to elucidate various aspects of this persistent colonization of this beneficial infection.

\section{H. PYLORI: CARRIED BY HUMAN OVER THE HISTORY}

It seems that $H$. pylori is an old recognized bacterium, which is not clinically comparable with new discovered infectious agents such as human immunodeficiency virus (HIV). In other words, HIV was introduced to human hosts $<50$ years ago. Given a long period of $H$. pylori colonization in the human stomach, mutual benefits obliged both partners to adapt themselves in order to establish stable symbiosis. It has been firmly established that $H$. pylori first subverts innate immunity and then modulates the adaptive immune system (blocking the activation of both $\mathrm{B}$ and $\mathrm{T}$ cells) (21-23). As a result, cagA and vacA, the main bacterial products, will inhibit $\mathrm{B}$ cell and $\mathrm{T}$ cell proliferation, respectively. Accordingly, immune response in the stomach is silenced against digested microbes $(24,25)$. Undeniably, the stomach, with its harsh acidic condition, is a container for many digested microbes every day. Possibly, regulation and modulation of immune response arose after microbial exposure to $H$. pylori colonizing the stomach $(24,25)$. Our current understanding of the strategies used by this pathogen to make a lifelong colonization, disclosed that maybe for our old ancestors having this bacteria in the stomach happened initially by accident, but due to natural selection, $H$. pylori made a set of adaptations, enabling the bacterium to survive and also thrive in the surface of human gastric epithelial cells. To everyone's surprise, after millions years of living in human stomach, $H$. pylori became a strategic member of our microbiome
(26). Undoubtedly, it is no exaggeration to say that both host and the bacterium are following a constant beneficial relationship, which is quite unique in biological world. After long period of $H$. pylori gastric colonization, it has evolved into a highly adaptable persistent bacterium, obtaining all necessary features of the most successful human pathogen.

\section{GERD AND H. PYLORI: A GOOD EXAMPLE OF BENEFICIAL EFFECTS}

Gastroesophageal reflux disease (GERD) incidence has been increased mostly in developed communities where $H$. pylori infection is almost effectively eradicated $(27,28)$. GERD is the main risk factor for Barrett's esophagus, and it has been associated with another deadly gastroduodenal carcinoma called "esophageal adenocarcinoma" $(3,5)$. However, the relationship between GERD and H. pylori remains incompletely defined (29). Several studies suggested that eradication of $H$. pylori infection in the setting of duodenal ulcer disease would result in an increase in GERD symptoms (3, 30). In other words, an inverse association of $H$. pylori infection with decreased rate of this sort of disease was a challenging topic in new gastroenterology $(14,31-33)$. Of note, GERD and its sequelae, which include Barrett's esophagus and esophageal adenocarcinoma, is decreasing in countries in which most individuals are infected by $H$. pylori $(15,34,35)$. Actually, not only has worldwide $H$. pylori prevalence changed in recent decades but also other environmental factors affecting on human health such as socioeconomical levels, diet, and vaccination were drastically changed $(10,17)$. If so, $H$. pylori is confronting with different situation rather than before. 
Remarkably, H. pylori can undergo drastic genetic change through each generation, while human genes do not change frequently. As a result, frequent genetic changes in $H$. pylori helped the bacterium to adapt quickly (18). Remarkably, slower adaptation in humans deteriorates longtime established equilibrium between $H$. pylori and human. Because of this, elimination of $H$. pylori as permanent resident of human microbiome would not be the first option to deal with gastroduodenal diseases. According to what explained about GERD and H. pylori as a protective effect, the long cohabitation in our stomach calls for more deep studies to elucidate microbiota and human health. GERD is the best example of disease, which became more frequent after starting the $H$. pylori treatment (34). Indeed, after antibiotic usage against $H$. pylori and, of course, its eradication in Western countries, a constant equilibrium between $H$. pylori and human health disappeared. Interestingly, in Northeastern Malaysia, the low prevalence of $H$. pylori infection was frequently reported (36-38). As general rule, one expects that frequency of diseases such as asthma and GERD should be relatively low rather than the findings of expected inverse association were not found (3941). Actually, the association between $H$. pylori infection and certain diseases such as GERD and asthma risk can be affected by geographical and genetic differences (37, 41). As a result, there is a complex and mostly undetermined associations between human microbiome and health; accordingly, all attempts to change this arranged biological system can exacerbate certain diseases. Undoubtedly, we need to eradicate virulent $H$. pylori in people with adverse clinical manifestations, but this conclusion cannot be generalized to all $H$. pylori positive subjects.

\section{FUTURE OF H. PYLORI}

The interesting relation between $H$. pylori and humans has shown that gastric acidic condition and human immune responses, which resulted in highly adaptable microbe. Currently, half of the world population is carrying strains that can survive and multiply in human gastric mucosa. Nowadays, available data about microbiota are sharply increasing; hence, one can expect to elucidate more details about this mysterious part of our bodies. In fact, experiments, which determine an actual association between $H$. pylori and microbiota, can increase our knowledge regarding this persistent resident of our stomach. Strikingly, both approaches, (i) bacterial eradication for asymptomatic individuals and (ii) global vaccination programs do not seem necessary in current clinical setting. Alternatively, we can suggest to only eradicating $H$. pylori in patients with adverse clinical presentations. In the end, with continuing current approach against $H$. pylori, we will lose this old ancient member of our microbiota; an event, which we are not fully aware of its drawbacks.

\section{ACKNOWLEDGMENTS}

The contents of the paper are the sole responsibility of the author and do not necessarily represent the official views of any institute or organization.

\section{REFERENCES}

1. Marais A, Monteiro L, Megraud F. Microbiology of Helicobacter pylori. Curr Top Microbiol Immunol (1999) 241:103-22.

2. Basso D, Plebani M, Kusters JG. Pathogenesis of Helicobacter pylori infection. Helicobacter (2010) 15(Suppl 1):14-20. doi:10.1111/j.1523-5378.2010. 00781.x

3. Kusters JG, Van Vliet AH, Kuipers EJ. Pathogenesis of Helicobacter pylori infection. Clin Microbiol Rev (2006) 19:449-90. doi:10.1128/CMR.00054-05

4. van Amsterdam K, Van Vliet AH, Kusters JG, Van Der Ende A. Of microbe and man: determinants of Helicobacter pylori-related diseases. FEMS Microbiol Rev (2006) 30:131-56. doi:10.1111/j.15746976.2005.00006.x

5. Gisbert J, Pajares J, Losa C. Helicobacter pylori and gastroesophageal reflux disease: friends or foes? Hepatogastroenterology (1998) 46:1023-9.

6. Chen Y, Blaser MJ. Helicobacter pylori colonization is inversely associated with childhood asthma. J Infect Dis (2008) 198:553-60. doi:10.1086/590158

7. Reibman J, Marmor M, Filner J, Fernandez-Beros ME, Rogers L, Perez-Perez GI, et al. Asthma is inversely associated with Helicobacter pylori status in an urban population. PLoS One (2008) 3:e4060. doi:10.1371/journal.pone.0004060

8. D’Elios MM, Codolo G, Amedei A, Mazzi P, Berton G, Zanotti G, et al. Helicobacter pylori, asthma and allergy. FEMS Immunol Med Microbiol (2009) 56:1-8. doi:10.1111/j.1574-695X.2009.00537.x

9. Amedei A, Codolo G, Del Prete G, De Bernard M, D'Elios MM. The effect of Helicobacter pylori on asthma and allergy. J Asthma Allergy (2010) 3:139-47. doi:10.2147/JAA.S8971

10. Lebwohl B, Blaser MJ, Ludvigsson JF, Green PH, Rundle A, Sonnenberg A, et al. Decreased risk of celiac disease in patients with Helicobacter pylori colonization. Am J Epidemiol (2013) 178:1721-30. doi:10.1093/aje/kwt234
11. Blaser MJ. Linking Helicobacter pylori to gastric cancer. Nat Med (2000) 6:376-7. doi:10.1038/ 74627

12. Fuccio L, Eusebi LH, Bazzoli F. Gastric cancer, Helicobacter pylori infection and other risk factors. World J Gastrointest Oncol (2010) 2:342-7. doi:10.4251/wjgo.v2.i9.342

13. Pandey R, Misra V, Misra SP, Dwivedi M, Kumar A, Tiwari BK. Helicobacter pylori and gastric cancer. Asian Pac J Cancer Prev (2010) 11:583-8.

14. Yaghoobi M, Farrokhyar F, Yuan Y, Hunt RH. Is there an increased risk of GERD after Helicobacter pylori eradication? A meta-analysis. Am J Gastroenterol (2010) 105:1007-1013; quiz 1006, 1014. doi:10.1038/ajg.2009.734

15. Saad AM, Choudhary A, Bechtold ML. Effect of Helicobacter pylori treatment on gastroesophageal reflux disease (GERD): meta-analysis of randomized controlled trials. Scand J Gastroenterol (2012) 47:129-35. doi:10.3109/00365521. 2011.648955

16. Dzierzanowska-Fangrat K, Dzierzanowska D. Helicobacter pylori: microbiology and interactions with gastrointestinal microflora. J Physiol Pharmacol (2006) 57(Suppl 3):5-14.

17. Cover TL, Blaser MJ. Helicobacter pylori in health and disease. Gastroenterology (2009) 136:1863-73. doi:10.1053/j.gastro.2009.01.073

18. Blaser MJ. Heterogeneity of Helicobacter pylori. Eur J Gastroenterol Hepatol (2012) 9(Suppl 1):S3-6. doi:10.1097/00042737-201204001-00002

19. Talebi Bezmin Abadi A, Taghvaei T, Mohabbati Mobarez A, Vaira G, Vaira D. High correlation of babA 2-positive strains of Helicobacter pylori with the presence of gastric cancer. Intern Emerg Med (2013) 8:497-501. doi:10.1007/s11739-0110631-6

20. Talebi Bezmin Abadi A. Therapy of Helicobacter pylori: present medley and future prospective. Biomed Res Int (2014) 2014:124607. doi:10.1155/ 2014/124607

21. Ernst PB, Pecquet S. Interactions between Helicobacter pylori and the local mucosal immune system. Scand J Gastroenterol Suppl (1991) 187:56-64. doi:10.3109/00365529109098225

22. Merrell DS, Falkow S. Frontal and stealth attack strategies in microbial pathogenesis. Nature (2004) 430:250-6. doi:10.1038/nature02760

23. Lee SK, Josenhans C. Helicobacter pylori and the innate immune system. Int J Med Microbiol (2005) 295:325-34. doi:10.1016/j.ijmm.2005.06.004

24. Fischer W, Gebert B, Haas R. Novel activities of the Helicobacter pylori vacuolating cytotoxin: from epithelial cells towards the immune system. Int J Med Microbiol (2004) 293:539-47. doi:10.1078/ 1438-4221-00300

25. Szczepanik M. Interplay between Helicobacter pylori and the immune system. Clinical implications. J Physiol Pharmacol (2006) 57(Suppl 3):15-27.

26. Sheh A, Fox JG. The role of the gastrointestinal microbiome in Helicobacter pylori pathogenesis. Gut Microbes (2013) 4:505-31. doi:10.4161/gmic. 26205

27. Graham DY. The changing epidemiology of GERD: geography and Helicobacter pylori. Am J Gastroenterol (2003) 98:1462-70. doi:10.1111/j.1572-0241. 2003.07533.x 
28. Falk GW. Evaluating the association of Helicobacter pylori to GERD. Gastroenterol Hepatol (N Y) (2008) 4:631-2.

29. Blaser MJ. Helicobacter pylori and esophageal disease: wake-up call? Gastroenterology (2010) 139:1819-22. doi:10.1053/j.gastro.2010.10.037

30. Xie T, Cui X, Zheng H, Chen D, He L, Jiang B. Meta-analysis: eradication of Helicobacter pylori infection is associated with the development of endoscopic gastroesophageal reflux disease. Eur J Gastroenterol Hepatol (2013) 25:1195-205. doi: 10.1097/MEG.0b013e328363e2c7

31. Graham DY. Helicobacter pylori is not and never was "protective" against anything, including GERD. Dig Dis Sci (2003) 48:629-30. doi:10.1023/ A:1022815902105

32. Somi MH, Fattahi E, Fouladi RF, Karimi M, Bonyadi R, Baballou Z. An inverse relation between CagA+ strains of Helicobacter pylori infection and risk of erosive GERD. Saudi Med J (2008) 29:393-6.

33. Rubenstein JH, Inadomi JM, Scheiman J, Schoenfeld P, Appelman H, Zhang M, et al. Association between Helicobacter pylori and Barrett's esophagus, erosive esophagitis, and gastroesophageal reflux symptoms. Clin Gastroenterol Hepatol (2014) 12:239-45. doi:10.1016/j.cgh.2013. 08.029

34. O'Morain CA, Qasim A. Motion - Helicobacter pylori worsens GERD: arguments for the motion. Can J Gastroenterol (2002) 16:611-4.
35. Jonaitis LV, Kiudelis G, Kupcinskas L. Characteristics of patients with erosive and nonerosive GERD in high-Helicobacter pylori prevalence region. Dis Esophagus (2004) 17:223-7. doi:10.1111/j.14422050.2004.00412.x

36. Lee YY, Ismail AW, Mustaffa N, Musa KI, Majid NA, Choo KE, et al. Sociocultural and dietary practices among Malay subjects in the NorthEastern Region of Peninsular Malaysia: a region of low prevalence of Helicobacter pylori infection. Helicobacter (2012) 17:54-61. doi:10.1111/j.15235378.2011.00917.x

37. Maran S, Lee YY, Xu SH, Raj MS, Abdul Majid $\mathrm{N}$, Choo KE, et al. Towards understanding the low prevalence of Helicobacter pylori in Malays: genetic variants among Helicobacter pylori negative ethnic Malays in the North-Eastern region of Peninsular Malaysia and Han Chinese and South Indians. J Dig Dis (2013) 14:196-202. doi:10.1111/17512980.12023

38. Lee YY, Noridah N, Syed Hassan SA, Menon J. Absence of Helicobacter pylori is not protective against peptic ulcer bleeding in elderly on offending agents: lessons from an exceptionally low prevalence population. PeerJ (2014) 2:e257. doi:10.7717/peerj.257

39. Quah B, Wan-Pauzi I, Ariffin N, Mazidah A. Prevalence of asthma, eczema and allergic rhinitis: two surveys, 6 years apart, in Kota Bharu, Malaysia. Respirology (2005) 10:244-9. doi:10.1111/j.14401843.2005.00645.x
40. Raj SM, Choo KE, Noorizan AM, Lee YY, Graham DY. Evidence against Helicobacter pylori being related to childhood asthma. J Infect Dis (2009) 199:914-5. doi:10.1086/597066

41. Lee YY, Mahendra Raj S, Graham DY. Helicobacter pylori infection - a boon or a bane: lessons from studies in a low-prevalence population. Helicobac$\operatorname{ter}$ (2013) 18:338-46. doi:10.1111/hel.12058

Conflict of Interest Statement: The author declares that the research was conducted in the absence of any commercial or financial relationships that could be construed as a potential conflict of interest.

Received: 08 June 2014; accepted: 12 August 2014; published online: 25 August 2014.

Citation: Talebi Bezmin Abadi A (2014) Helicobacter pylori: a beneficial gastric pathogen? Front. Med. 1:26. doi: 10.3389/fmed.2014.00026

This article was submitted to Gastroenterology, a section of the journal Frontiers in Medicine.

Copyright (c) 2014 Talebi Bezmin Abadi. This is an openaccess article distributed under the terms of the Creative Commons Attribution License (CC BY). The use, distribution or reproduction in other forums is permitted, provided the original author(s) or licensor are credited and that the original publication in this journal is cited, in accordance with accepted academic practice. No use, distribution or reproduction is permitted which does not comply with these terms. 